\title{
Intensifying of Stock Markets (DSE \& CSE) in Bangladesh: An Experiment
}

\author{
Syed Nazmul Huda
}

Assistant Professor, Department of Business Administration, Asian University of Bangladesh, Bangladesh

\begin{abstract}
A stock market plays as a strong role in the industrialization and economic development of the country. Among the developing countries, the contribution of the capital market have lately been recognized. This paper assess the Intensifying of Stock Markets (DSE \& CSE) in Bangladesh based on Dhaka Stock Exchange (DSE) \& Chittagong Stock Exchange (CSE). Information collected from secondary data during 2000-2011 along with identifying the major dominants factors and some problems or lacks of stock market whish is greatly obstacle to intensifying the stock market in Bangladesh. By using the factor analysis it has been shown that Turn over of capital market largely depends on four indicators i.e. No. of Listed Securities, Initial Public Offering (IPOs), Market Capitalization, Issued Capital in the both stock markets in Bangladesh during the study period. The authors to identify the some problems or lacks of stock market in Bangladesh which has been face the market crash in recent years and doing experiment to find out the dominants factors to overcome problems as well as develop the stock market during the study period.
\end{abstract}

\section{Keywords: Dhaka Stock Exchange, Chittagong Stock Exchange and Keiser Mayer Olkin}

\section{INTRODUCTION}

$\mathrm{T}$ The The capital market in Bangladesh is still at a developing stage. Bangladesh capital market is one of the smallest in Asia but the third largest in the south asia region. It has two automated stock exchanges namely Dhaka stock exchange and Chittagong stock exchange. The Dhaka Stock Exchange (DSE) and Chittagong Stock Exchange (CSE) has undergone significant changes contributing towards the development of Bangladesh capital market. The development of the capital market is crucial for capital accumulation, efficient allocation of resources and promotion of economic growth. Capital markets of different countries of the world collapsed in the face of global recession, the capital markets of Bangladesh remained quite buoyant at that time. Given the growing number of ordinary investors in capital markets, limited supply of securities and investors' expectations for more profit at times made the market volatile. Nevertheless, various steps have been taken to maintain market stability and to establish a transparent and vibrant capital market while deepening it. The Government has also started off-loading state-owned companies' shares. Already, 5 state-owned companies have completed off-loading of shares. As a result, confidence on capital market of local and foreign investors has increased. The Securities and Exchange Commission (SEC) has strengthened its surveillance on securities transactions and supervision on market intermediaries so that market operates in transparent manner. The stock market was in turbulence throughout much of 2009 , with the long bullish trend starting to turn grim. The bullish trend was initiated by the end of the two-year political crisis and re-emergence of democracy via the December 2008 polls, and was largely unaffected by the BDR Mutiny. The market was heavily aided by the entrance of
Grameenphone into the capital market, when the index rose by $22 \%$ over a single day on November 16, 2009. Share prices continued to fluctuate, reaching the annual high in mid 2009 before plummeting by the end of 2009 . The market continued to be turbulent throughout 2010, with the DSE hitting it's all time high revenue and the largest fall in a single day since the 1996 market crash, within the space of a month. By the end of 2010, it was well known that the capital markets of Bangladesh well overvalued and overheated. The central bank had taken measures to cool the market down and control inflation by putting a leash on the liquidity. The capital markets suffered a second fall on December 19, with the index falling a further 551 points, or about $7 \%$. This $7 \%$ fall in the Dhaka Stock Exchange's index on a single day was the largest fall in the 55 year history of the Exchange, surpassing the fall of the 1996 market crash.

\section{Objectives of the Study}

The selected of objectives of the study are as follows:

- To show up the history of stock market in Bangladesh.

- To illustrate the present status of the stock market in Bangladesh.

- To experiment the major dominant factors of the Dhaka Stock Exchange (DSE) \& Chittagong Stock Exchange (CSE) during the study period.

- To summarize the some problems or lacks to intensifying the stock market in Bangladesh during the study period. 


\section{ReVIeW Works}

Keeping the objectives in mind of the present study, we had reviewed the existing literatures. The importance of the capital market lies in the fact that it is the primary source of external funds for corporate investment (Jensen and Murphy,1990). A number of recent theoritical contributions suggest that stock markets promote long term growth. Welldeveloped stock markets give due return to prudently-managed firms in the form of rising shareholders, wealth which may increase payment of managers. The stock market contributes to economic development as it facilitates equity finance, spreads ownership among a large set of investors and thus mobilize the saving of the population, provides a mechanism for allocating capital to productive use and facilitates a link between the capital markets of a particular country and the markets of the industrial world (Ryrie, 1991). The proponents of stock market emphasize the importance of having a "developed" stock market in enhancing the efficiency of investment. A well functioning stock market is expected to lead a lower cost of equity capital for firms and allow individuals to more effectively price and hedge risk ( Bepari M.K. and Mollik A, 2006). In contrast, Stiglitz (1993) argues that stock market liquidity does not enhance incentives for acquiring information about firms or improving corporate governance. Shleifer and Vishny (1986) and Bhide (1993) argue that more liquidity reduces the incentives of shareholders to undertake the costly task of monitoring managers resulting in weaker corporate governance and slowdown in effective resource allocation decelerating productivity growth. Corbett and Jenkinson (1994), while discussing the contribution of stock market to corporate investment financing, suggest that it was negative in the United Kingdom and only marginally positive in the United States during the 1970's and the 1980's. Bencivenga et al. (1995) formulate models where more liquid stock market ( less expensive to trade equities ) encourages investors to fund long duration projects because investors can easily sell their stakes in the projects if they need their savings before the projects matures. Investors in Bangladesh became increasingly interested in equity markets because many enterpreneurs look for requirements from the equity markets for many reasons and dse and cse play an integral role in the pace of industrialization of the country (Akhter S et al, 2005). Dermirguc-Kunt and Levine (1996), Singh (1997) and Levine and Zervos (1998) found that stock market growth plays an important role in predicting future economic growth in situations where the stock markets are active.

\section{Statement of the Problems}

There was a little scope for research on this crucial subject as all the data was secondary and no way to collect primary data was available. Lack of a wider coverage due to time constraint. We did not have much time to visit all the relevant places and meet respective personnel. Stock markets are great financial institutions for economic growth provided they are managed properly. Billions of dollars worth of capital can be raised from millions of investors, small and large with voluntary participation. Some well

Copyright (C) 2013, Asian Business Consortium | ABR founded theories have been established by scholars after studying the operation of stock markets in the developed world. The Government of Bangladesh always gets low return from GDP as the level of productivity is very poor. Similarly Government revenue is also very poor as compared to the expenditure status of the country. The factors like unfavourable balance of payment \& trade, high level of poverty \& low level of savings, unemployment, frequent natural disaster, industrial sickness, high level of dependence on import, unfair competition etc are the main causes for declining efficiency of the capital market in Bangladesh and hence the status of the capital market is yet underdeveloped. While conducting the study, we were confronted with the some limitations. There is no alternative of primary data to ensure the accuracy and effectiveness of the study. Considering these the present study is planned.

\section{Methodological Aspects}

This paper is based on secondary information. Data on different variables of the stock market are collected from annual reports of Security and Exchange Commission (SEC) of Bangladesh, Dhaka Stock Exchange (DSE), and Chittagong Stock Exchange (CSE), relevant articles, journals, Bangladesh Economic Survey during 2000-2011, Bangladesh Economic Review during 2000-2011and daily newspapers etc. For analyzing the data, major statistical tools like factor analysis, KMO Bartlestt's Test, Total Variance Explained, Eigenvalues, Extraction Sum of Squared Loadings, Rotation Sum Squared Loadings R2, Adjusted R2, F Change, \& regression analysis etc. have been used for the study using the software Statistical Package for Social Science (SPSS) information regarding Turnover, No. of Listed Securities, Initial Public Offering (IPOs), Market Capitalization, Market Capitalization (as \% of GDP), Issued Capital, Price Index, Cash Dividend \& GDP. This study covered 12 years i.e. 2000 - 2011.

\section{History OF Stock MARKET In BANGLADESH}

Capital market concepts started in USA at Wall Street in 1653. It came to South Asia in 1890. The Bangladesh capital market operations in this part of the country started in mid fifties with the establishment of East Pakistan Stock Exchange Association in 1954, which started trading in 1956. Initially it was a mutual organization (cooperative body) which was corporatized in recent activity of the Dhaka Stock Exchange (DSE) in term of turn over in the name of Dacca Stock Exchange Ltd. During those early periods until 1971, all trades in the exchange were conducted using trading data collected over telephone from Karachi Stock Exchange. After independence of Bangladesh, the operations of the stock exchange remained suspended until August 1976. At that time market trading started with only 14 listed companies having market value of only taka 90 million. The trade volume was very thin and could not attract investors. Over time some reform initiatives were taken to strengthen the market. First time 
Tk. 1 crore daily trades were recorded in April 1992. Government adopted the Securities and Exchange Commission Act 1993 and established the SEC as the regulatory authority for the market and the Securities and Exchange Commission (SEC), established in 1993 under this Act, as the central regulatory agency oversees the activities of the entire capital market including issue of capital, monitoring the issue of stocks and operation of the stock markets including regulating of portfolio market. A big wing of Bangladesh capital market, Chittagong Stock Exchange (CSE) incorporated in 1995. Bangladesh Capital Market products are as Shares, Debentures, Mutual Funds, Bonds, Derivates, Future and Options etc. On the other hand Capital Market Players are as Securities and Exchange Commission (SEC), Stock Exchange (DSE \& CSE), Private Limited Company, Brokers and Dealers, Merchant Banks, Investors, and Central Depository Bangladesh Limited (CDBL). At Present Bangladesh has two stock exchanges i.e. Dhaka Stock Exchange (Number of registered trading Members/Brokers is 195) and Chittagong Stock Exchange (Number of registered trading Members/Brokers is 124). The market capitalization of Dhaka Stock Exchange is BDT 104700 million and the market capitalization of Chittagong Stock Exchange is BDT 800000 million. Bangladesh Capital market is growing day by day, now there are two exchanges with 276 companies, 17 mutual funds, 8 debentures and 112 bond.

\section{Present Status of Stock Market in BANGLADESH}

The stock markets of Bangladesh were buoyant during 2009-10, but it became volatile from the second half of 2010-11. The market capitalisation of the Dhaka Stock Exchange (DSE) rose from 39.00 percent of GDP at the end of 2009-10, which was 21.4 percent of GDP at the end of 2008-09. During this period, the DSE general index increased by 98.43 percent from 3,010.26 to 6,153.68 indicating keen interests showed by the investors in the capital market. By the end of June 2010, the number of BO (Beneficiary Owner) accounts has increased to 25.64 lakh from 14.15 lakh at the end of June 2009. At the beginning of 2010-11, the capital market showed buoyant. The DSE general index stood at 8,290.41 in December 2010, up by 34.72 percent compared to June 2010. Similarly, market capitalisation stood at 44.1 percent at that time. However, the overheated capital markets undergone sharp price correction in January 2011 and was in process of recovery and stabilization during the last quarter of 2010-11. Market capitalisation and general index of DSE stood at 36.24 percent of GDP and 5,093.19 at the end of 2010-11. Albeit Bangladesh economy is not more integrated with the global economies, Global Financial Crisis 2008 has dented every sphere of Bangladesh. Bangladesh economy has also been limping since being dented by the blow of financial meltdown. On the other hand, Bangladesh economy has been gaining benefits from the crisis and it has lost. Because of income declining of developed countries' citizen slow-priced garments of Bangladesh has been very popular registering more growth in the country's apparel secCopyright @ 2013, Asian Business Consortium | ABR tor. But financial collapse in many developed countries slowed down the infrastructural development especially construction works in Middle East which have pushed many Bangladeshi workers come back. Remittance inflow has risen but number of workers going abroad has fallen drastically. Country's foreign currency reserve hit new record of $\$ 11.35$ billion recently because of low import expenditure and rising trend of export earnings. But still 44 percent people are under poverty level; the Government and other concerned organizations should take comprehensive efforts to eradicate poverty. But to achieve desired level of growth to turn Bangladesh into a middle income country by 2021, growth rate should be accelerated. To do that more investment in infrastructure especially power sector, roads and highway, modern and sophisticated port facilities are badly needed. Cost of doing business should also be reduced along with the removal of redtops in commencing business. Public-Private Partnership has been incorporated in the budget for 2010-11 but success will depend on time bound implementation. Instead of eying towards foreign countries, multi-lateral donors and agencies Government should choose country's capital market to raise fund for development projects especially for the construction of Padma Bridge, elevated express way and other big projects which will also ensure people's association in profitable Government properties. Associating general people in lucrative Government venture means to create the way of ensuring equitable distribution of wealth and this is only possible through strong and vibrant capital market. Because of sluggish economic activities investment has not gotten momentum in recent years but for the sake of rapid economic growth more savings and investment are also necessary. Another important issue is that tax to GDP (Gross Domestic Product) is very poor in Bangladesh, which has been another cause of fiscal deficit in almost every year. The Government has been regularly depending upon the borrowing both from internal and external sources. Instead of borrowing from banking sources and other foreign lenders Government should depend on raising fund from the country's capital market. Government borrowing from the country's formal banking sector private industrial ventures and other commercial set ups have been on declining trend.

\section{Data Analysis \& MaJor Findings of the STUDY}

It has two full fledged automated stock exchanges: Dhaka Stock Exchange and Chittagong Stock Exchange. Capital market plays a significant role in the economy as a source of long term financing. Factor analysis for Dhaka Stock Exchange is to identify the dominants factors during 2000-2011. Factor analysis provided by the use of data of Table 1 is shows in below:

\section{Insert Table 1 Here}

The table shows the results of Kaiser-Meyer-Olkin (KMO) \& Bartlett's Test of factors of Dhaka Stock Exchange (DSE) based on the information of selected variables during 
2000-2011. High values (between 0.50 and 1.00) indicate that factor analysis is appropriate. The value of $\mathrm{KMO}$ $>0.50$ to $<0.70$ is represent the Mediocre, value of KMO $>0.70$ is represent the Good Performance, value of KMO $>0.80$ is represent the Very Good Performance. In this case, $\mathrm{KMO}$ reveals the sampling adequacy indicating i.e. 0.643 for Dhaka Stock Exchange (DSE) i.e. mediocre performance for the same. Bartlett's Test of Sphericity indicates that the approximate chi-squire value is 145.45 of Dhaka Stock Exchange (DSE) with 36 (df) for at $0.000 \mathrm{lev}$ els of significance. Hence, the factor analysis is considered as an appropriate technique for analyzing the data, which shows the satisfactory results for the same. From the analyze of Table No. 1 we found that only 4 indicators that highly dominants the stock market operations, on which the present study has been analyzed in order to obtain the research goal.

\section{Insert Table 2 Here}

According to the Total Variance Explained (a), we find that the Eigen Values are greater than 1 (One), these four factors are being extracted for Dhaka Stock Exchange (DSE). These imply that performance of Dhaka Stock Exchange (DSE) depends on four major factors. Cumulative percentage rates i.e. $68.66,90.03,95.47 \& 98.99$ percent for Dhaka Stock Exchange (DSE) and the remaining variables collectively explain the balance like 99.74, 99.89, 99.95, $99.99 \& 100.00$ percent of total variance. Hence we can reduce the number of variables to 4 out of 9 for the selected variables under the study. Extraction Sums of Squared Loadings indicates the percentage of variance shows only two factors i.e. $68.66 \& 21.37$ including total position of the same was 5.15 \& 1.83 respectively. Rotation Sums of Squared Loadings also indicates the percentage of variance shows only two factors i.e. $62.82 \& 20.88$ including total position of the same was $4.92 \& 1.06$ respectively. Regression Analysis: After identifying the major influencing selected variables, we further proceed for regression analysis considering turnover as dependent variable. The regression analyses have been done using the software SPSS and the results of the regression analyses have been shown by the table 3 .

\section{Insert Table 3 Here}

Regression Analysis reveals that Turnover has a significant relation with independent variables i.e. No. of Listed Securities, Initial Public Offering (IPOs), Issued Capital, Market Capitalization, Price Index, Cash Dividend, GDP, Market Capitalization (as \% of GDP) of the Dhaka Stock Exchange (DSE) during the period 2000-2011. The Regression analysis tool performs linear regression analysis by using the "least squares" method to fit a line through a set of observations. Model summary indicates that, $\mathrm{R}=0.97 \%$ (selected) \& $0.82 \%$ (Unselected) i.e. near about 1 , so it is a favourable sign for the same. This indicates the high degree of linear association between dependent \& independent variables as a whole. The $\mathrm{R}$ Square value is 0.96 Copyright (C) 2013, Asian Business Consortium | ABR indicates the goodness of fit of the regression model. Estimated regression model shows that about $95 \%$ of the total variation of the dependent variable is explained by the selected explanatory variables and the result is significant for the study. The calculated value of $\mathrm{F}$ is greater that than that of the tabulated value at $5 \%$ level of significance for df 1 (8) \& df 2 (6) degrees freedom.

Factor Analysis for Chittagong Stock Exchange (CSE): Factor analysis is to identify the most dominants factors of Chittagong Stock Exchange during 2000-2011. Factor analysis provided by the use of data of Table 4 .

\section{Insert Table 4 Here}

Table 4 shows the results of Kaiser-Meyer-Olkin (KMO) \& Bartlett's Test of factors of Chittagong Stock Exchange (CSE) based on the information of selected variables during 2000-2011. In this case, KMO reveals the sampling adequacy indicating i.e. 0.565 for Chittagong Stock Exchange (CSE) i.e. mediocre performance for the same. Bartlett's Test of Sphericity indicates that the approximate chi-squire value is 187.85 of Chittagong Stock Exchange (CSE) with 36 (df) for at 0.000 levels of significance. Hence, the factor analysis is considered as an appropriate technique for analyzing the data, which shows the satisfactory results for the same. From the Table No. 4 we found that only 4 indicators that highly influence the capital market operations, on which the present study has been analyzed in order to obtain the research goal.

\section{Insert Table 5 Here}

The table 5 shows the Total Variance Explained (a), we find that the four factors are being extracted for Chittagong Stock Exchange (CSE). These imply that performance of Chittagong Stock Exchange (CSE) depends on four major factors. Cumulative percentage rates i.e. 69.75, 89.64, 95.86 \& 98.04 percent for Chittagong Stock Exchange (CSE) and the remaining variables collectively explain the balance like 98.83, 99.50, 99.93, $99.97 \& 100.00$ percent of total variance. Hence we can reduce the number of variables to 4 out of 9 for the selected variables under the study. Extraction Sums of Squared Loadings indicates the percentage of variance shows only two factors i.e. $69.75 \& 15.54$ including total position of the same was 6.81 \& 1.47 respectively. Rotation Sums of Squared Loadings also indicates the percentage of variance shows only two factors i.e. $73.09 \& 11.93$ including total position of the same was 6.75 \& 1.52 respectively. Regression Analysis: we further proceed for regression analysis considering turnover as dependent variable. The regression analyses have been done using the software SPSS and the results of the regression analyses have been shown by the table 6 .

\section{Insert Table 6 Here}

The table 6 represent the Turnover has a significant relation with independent variables i.e. No. of Listed Securities, Initial Public Offering (IPOs), Issued Capital, Market Capitalization, Price Index, Cash Dividend, GDP, Market 
Capitalization (as \% of GDP), of the Chittagong Stock Exchange (CSE) during the period 2000-2011. Model summary indicates that, $\mathrm{R}=0.95 \%$ (Selected) \& $0.96 \%$ (Unselected) i.e. near about 1 , so it is a variability of the dependent variable is explained by the predictors and also favourable sign for the same. This indicates the high degree of linear association between dependent \& independent variables as a whole. The R Square value is 0.93 indicates the goodness of fit of the regression model. The calculated value of $\mathrm{F}$ is greater that than that of the tabulated value at $5 \%$ level of significance for $\mathrm{df} 1$ (8) \& df 2 (6) degrees freedom.

\section{Some Problems of Intensifying the Stock MARKET IN BANGLADESH}

After analyzing the dominants factors of both Dhaka Stock Exchange (DSE) \& Chittagong Stock Exchange (CSE) we found the following some problems or lacks which is greatly obstacle to intensifying the stock market in Bangladesh whish are shown below:

- Enforcement with the compliance of rules and regulations.

- Ethical orientation, education about capital \& securities markets.

- Unavailable steps to identify the problems of book building method and make correction of the system.

- Inefficient capital market both operational and informational

- Substantial facilities and infrastructure of the Capital Market in Bangladesh.

- Potential securities and narrow options for the investors.

- Continuation of only dealer broker members.

- Market dominated largely by unsophisticated investors.

- Diversity in products' availability in the market

- Proper and adequate disclosures Certifiers of financial statements

- Corporate governance sponsor owners are managing the firm.

- Irregular declaration for dividend.

- Infusion of fake shares.

- Exaggerated projection in prospectuses.

- The environment of investment is unsuitable.

- Political unrest

- Due to controllable \& uncontrollable factors.

- Due to high risk \& uncertainty prevailing in the capital of Bangladesh.

- Industrial sickness of the capital market of Bangladesh

- Financial statements of the company are not prepared in time.

- Unskilled, incompetent and unqualified people.

\section{CONCLUSION}

Stock market plays a significant role in the economy as a source of long term financing. The contribution of the stock market to the economy of Bangladesh has been increasing day by day. The economic growth of an country like Bangladesh mainly depends on the development of stock market. An efficient and transparent capital market contributes to industrialization and economic development of any country. We should take this opportunity to boost up the market as well as contribute to our economy. Foreign investments also need to be increased to ensure a sound capital and along with this, the government should make an authentic list of the companies that has credibility and accountability. Both Dhaka Stock Exchange (DSE) \& Chittagong Stock Exchange (CSE) are operated capital market in Bangladesh with more contribution in economy of Bangladesh. Both are most essential part of the country's developing. But after analyzing we found that Dhaka Stock Exchange are more contributor than Chittagong Stock Exchange for the economic development of Bangladesh. Hence, at present capital market has been facing huge market crash \& decreasing the price index during the last two years. So, a strong capital market acts as a vehicle for growth of the economy. Therefore, it should be the joint responsibility of the regulators, the exchanges, Securities and Exchange Commission and the government to properly discharge their due roles. There must also be adequate, update and relevant information flow from the listed companies \& joint initiatives of the SEC to the investors at the after checking and re-checking them properly. Concerned agencies should also educate the investors. Investment facilities and law and order situation of the country need improvement. The government has sophisticated plan but it has not been that effective for the revival of foreign investment. Last but not the least, the market intermediaries including the financial intermediaries must discharge their responsibilities to boost the capital market. Specific recommendations for improving the roles of regulators as provided in this paper to improve long way in activating capital market and ensuring on, they are to build their image as a necessary alternative by maintaining a smooth relation public confidence. Finally, developing countries which accounts for $75 \%$ of the world's population, have an enduring need to attract capital and technology to improve their infrastructure and standard of living. Developing economies, thus, look forward to their capital markets as the engine for future growth as its existence ensures mobilization of surplus funds to the ones suffering from deficit. There is an initiative to frame Financial Reporting Act to maintain stability in capital market. The government has been considering a plan to establish a Financial Reporting It is expected that these initiatives will regain investors' confidence in the capital market. Ensuring effective monetary management and developing an efficient and reliable financial market are the prerequisites for achieving the goals of macroeconomic stability in Bangladesh. 


\section{REFERENCES}

Akhter S. Misir A, Ahmed S (2005) "Capital markets development in Bangladesh the status of DSE", Pakistan Journal of Social Science 3(8), 1002-1006, 2005.

Bangladesh Economic Review (2011), Economic Advisor's Wing, Finance Division, Ministry of Finance.

Bencivenga, Valerie R., Smith, Bruce D. and starr, Ross M. (1995), Transactions costs, Technological choice and Endogenous growth', Journal of Economic Theory, 67(1), 53-177.

Bepari MK \& Mollik a (2008), "Bangladesh stock Market growing? Key indicators based assessment", Online publication.

Corbett, Jenny and Jenkinson, Tim(1994), The Financing of industry, 19701989: An international comparison' Discussion paper No. 948, London: Centre for economic policy research.
Demirguc-Kunt, Asli and Ross, Levine (1996). "Stock market growthand financial intermediaries: sylized facts", The world Bank Economic Review, Vol. 10(2), pp.291-232.

Haque, M. S. (1992) "Development of Capital Markets in Bangladesh", Bank Parikrama, Vol. XVII.

Jensen, Michael C, and Murphy, Kevin J. (1990)."Performance pay and Top management incentives", Journal of political economy, 98, 225-64.

Ryrie, William. (1991). "Stock market their role in economic development", The Stock Exchange Review.

Shleifer, Andrei and Vishny, robert W. (1986). "Large shareholders and corporate control" journal of political economy, 96(3), 461-88.

Stiglitz, J. (1993). " The role of the state in financial markets", Proceedings of the annual Bank Conference on development economics, pp.19-52.

Table 1: Trading Operation in Dhaka Stock Exchange Ltd. during 2000-2011.

\begin{tabular}{|c|c|c|c|c|c|c|c|c|c|}
\hline Year & $\begin{array}{c}\text { Turnover } \\
\text { (In crore } \\
\text { Tk.) }\end{array}$ & $\begin{array}{c}\text { No. of } \\
\text { Listed } \\
\text { Securities }\end{array}$ & $\begin{array}{c}\text { Initial } \\
\text { Public } \\
\text { Offering } \\
\text { (IPO) }\end{array}$ & $\begin{array}{c}\text { Isssued } \\
\text { Capital } \\
\text { (In crore } \\
\text { Tk.) }\end{array}$ & $\begin{array}{c}\text { Market } \\
\text { Capitalisation } \\
\text { (In crore Tk.) }\end{array}$ & $\begin{array}{c}\text { GDP } \\
\text { (In crore } \\
\text { Tk.) }\end{array}$ & $\begin{array}{c}\text { Market } \\
\text { Capitali } \\
\text {-sation } \\
\text { (as \% of GDP) }\end{array}$ & $\begin{array}{c}\text { Price } \\
\text { Index }\end{array}$ & $\begin{array}{c}\text { Cash } \\
\text { Dividend }\end{array}$ \\
\hline 2000 & 4036.48 & 241 & 7 & 3119.20 & 6292.40 & 253543.50 & 2.48 & 642.68 & 145.30 \\
2001 & 3986.83 & 249 & 11 & 3345.43 & 6522.28 & 273200.01 & 2.39 & 817.79 & 149.54 \\
2002 & 3498.49 & 260 & 8 & 3520.30 & 7126.70 & 300567.80 & 2.37 & 822.34 & 150.15 \\
2003 & 1915.21 & 267 & 14 & 4605.50 & 9758.70 & 332975.70 & 2.93 & 967.88 & 151.87 \\
2004 & 5318.11 & 256 & 2 & 4953.20 & 22492.30 & 332973.70 & $6.75 \%$ & 1971.31 & 153.20 \\
2005 & 6483.48 & 286 & 22 & 7031.30 & 22829.00 & 370707.10 & $6.16 \%$ & 1275.05 & 133.10 \\
2006 & 6506.93 & 310 & 12 & 11843.70 & 31544.60 & 415728.60 & $7.59 \%$ & 1321.39 & 125.25 \\
2007 & 32282.01 & 350 & 14 & 21447.00 & 74219.60 & 472477.80 & $15.71 \%$ & 2535.96 & 130.20 \\
2008 & 66796.47 & 412 & 12 & 37215.60 & 104379.00 & 545822.20 & $19.12 \%$ & 2309.96 & 135.00 \\
2009 & 147530.08 & 415 & 18 & 52209.90 & 190322.80 & 614795.40 & $30.96 \%$ & 3747.53 & 139.00 \\
2010 & 400991.30 & 445 & 18 & 66434.00 & 350800.60 & 692380.50 & $50.67 \%$ & 6877.70 & 141.10 \\
2011 & 156091.20 & 501 & 14 & 87890.50 & 261679.10 & 701254.10 & $37.32 \%$ & 4383.90 & 140.00 \\
\hline
\end{tabular}

Source: Dhaka Stock Exchange (DSE).

KMO and Bartlett's Test (a)

\begin{tabular}{|l|l|r|}
\hline \multicolumn{2}{|l|}{$\begin{array}{l}\text { Kaiser-Meyer-Olkin Measure } \\
\text { of Sampling Adequacy. }\end{array}$} & $\mathbf{0 . 6 4 3}$ \\
\hline $\begin{array}{l}\text { Bartlett's Test } \\
\text { of Sphericity }\end{array}$ & $\begin{array}{l}\text { Approx. } \\
\text { Chi-Square }\end{array}$ & 145.45 \\
\hline & df & 36 \\
\hline & Sig. & 0.000 \\
\hline
\end{tabular}

a. Only cases for DSE are used in the analysis phase.

Table 2: Total Variance Explained (a)

\begin{tabular}{|c|c|c|c|c|c|c|c|c|c|}
\hline Component & \multicolumn{3}{|c|}{ Initial Eigenvalues } & \multicolumn{3}{|c|}{ Extraction Sums of Squared Loadings } & \multicolumn{3}{c|}{ Rotation Sums of Squared Loadings } \\
\hline & Total & $\begin{array}{c}\% \text { of } \\
\text { Variance }\end{array}$ & $\begin{array}{c}\text { Cumu } \\
\text { lative } \%\end{array}$ & Total & $\begin{array}{c}\% \text { of } \\
\text { Variance }\end{array}$ & $\begin{array}{c}\text { Cumula } \\
\text { tive \% }\end{array}$ & Total & $\begin{array}{c}\% \text { of } \\
\text { Variance }\end{array}$ & $\begin{array}{c}\text { Cumula } \\
\text { tive \% }\end{array}$ \\
\hline 1 & 6.15 & 68.66 & 68.66 & 5.15 & 68.66 & 68.66 & 4.92 & 62.82 & 62.82 \\
\hline 2 & 1.83 & 21.37 & 90.03 & 1.83 & 21.37 & 90.03 & 1.06 & 20.88 & 83.70 \\
\hline 3 & 0.49 & 5.44 & 95.47 & & & & & & \\
\hline 4 & 0.31 & 3.52 & 98.99 & & & & & & \\
\hline 5 & 0.18 & 0.75 & 99.74 & & & & & & \\
\hline 6 & 0.01 & 0.15 & 99.89 & & & & & & \\
\hline 7 & 0.00 & 0.06 & 99.95 & & & & & & \\
\hline 8 & 0.00 & 0.04 & 99.99 & & & & & & \\
\hline 9 & 0.00 & 0.01 & 100.00 & & & & & & \\
\hline
\end{tabular}

Extraction Method: Principal Component Analysis. a Only cases for DSE are used in the analysis phase. 
Table 3: Model Summary

\begin{tabular}{|c|c|c|c|c|c|c|c|c|c|c|}
\hline $\begin{array}{l}\overrightarrow{0} \\
\frac{0}{8} \\
\end{array}$ & \multicolumn{2}{|c|}{$\mathrm{R}$} & \multirow[t]{2}{*}{$\mathrm{R}^{2}$} & \multirow[t]{2}{*}{ Adjusted $\mathrm{R}^{2}$} & \multirow{2}{*}{\begin{tabular}{|l|} 
Std. Error of \\
the Estimate \\
\end{tabular}} & \multicolumn{5}{|c|}{ Change Statistics } \\
\hline & DSE (Selected) & DSE (Unsel.) & & & & $\mathrm{R}^{2}$ Change & F Change & df1 & $\mathrm{df} 2$ & Sig. F Change \\
\hline 1 & $0.97(\mathrm{a})$ & 0.82 & 0.96 & 0.95 & 1543.78 & 0.97 & 112.67 & 8 & 6 & 0.00 \\
\hline
\end{tabular}

a Predictors: (Constant), Initial Public Offering (IPOs), Price Index, Cash Dividend, Issued Capital, GDP, No. of Listed Securities, Market Capitalization.

$b$ Unless noted otherwise, statistics are based only on cases for DSE. c Dependent Variable: Turnover

Table 4: Trading Operation in Chittagong Stock Exchange Ltd. during 2000-2011.

\begin{tabular}{|c|c|c|c|c|c|c|c|c|c|}
\hline Year & $\begin{array}{c}\text { Turnover } \\
\text { (In crore } \\
\text { Tk.) }\end{array}$ & $\begin{array}{c}\text { No. of } \\
\text { Listed } \\
\text { Securities }\end{array}$ & $\begin{array}{l}\text { Initial } \\
\text { Public } \\
\text { Offering } \\
\text { (IPO) }\end{array}$ & $\begin{array}{c}\text { Isssued } \\
\text { Capital } \\
\text { (In crore Tk.) }\end{array}$ & $\begin{array}{c}\text { Market } \\
\text { Capitalisation } \\
\text { (In crore Tk.) }\end{array}$ & $\begin{array}{c}\text { GDP } \\
\text { (In crore Tk.) }\end{array}$ & $\begin{array}{c}\text { Market } \\
\text { Capitalisation } \\
\text { (as \% of GDP) }\end{array}$ & $\begin{array}{l}\text { Price } \\
\text { Index }\end{array}$ & $\begin{array}{c}\text { Cash } \\
\text { Dividend }\end{array}$ \\
\hline 2000 & 1293.38 & 165 & 3 & 2726.60 & 5776.55 & 253543.50 & 2.48 & 1412.25 & 138.88 \\
\hline 2001 & 1479.62 & 177 & 9 & 2965.27 & 5636.35 & 273200.01 & 2.39 & 1836.87 & 139.21 \\
\hline 2002 & 1358.61 & 185 & 9 & 3107.99 & 6046.77 & 300567.80 & 2.37 & 1841.14 & 140.45 \\
\hline 2003 & 668.86 & 199 & 10 & 4196.76 & 8531.23 & 332975.70 & 2.93 & 1642.78 & 141.35 \\
\hline 2004 & 1755.13 & 195 & 3 & 4697.87 & 21501.08 & 332973.70 & 6.46 & 3597.70 & 142.00 \\
\hline 2005 & 1404.27 & 210 & 16 & 5551.93 & 21994.28 & 370707.10 & 5.93 & 3378.68 & 149.00 \\
\hline 2006 & 1589.31 & 213 & 6 & 6937.84 & 27051.07 & 415728.60 & 6.51 & 3724.39 & 145.00 \\
\hline 2007 & 5259.03 & 227 & 13 & 8917.39 & 61258.00 & 472477.80 & 12.97 & 7657.06 & 142.00 \\
\hline 2008 & 9980.37 & 238 & 12 & 12160.32 & 80768.40 & 545822.20 & 14.80 & 8692.75 & 149.00 \\
\hline 2009 & 16256.26 & 217 & 18 & 15512.49 & 147080.70 & 614795.40 & 23.92 & 13181.37 & 151.00 \\
\hline 2010 & 21520.40 & 232 & 18 & 20111.56 & 253439.33 & 692380.50 & 39.45 & 18116.10 & 150.00 \\
\hline 2011 & 18633.80 & 241 & 6 & 32212.90 & 197242.30 & 701254.10 & 28.95 & 14880.40 & 152.00 \\
\hline & & & & \multicolumn{2}{|c|}{ Source: Chittagong Stock Exchange. } & $\begin{array}{l}\text { hange. } \\
\text { est (a) }\end{array}$ & & & \\
\hline & & & \multicolumn{4}{|c|}{ Kaiser-Meyer-Olkin Measure of Sampling Adequacy. } & 0.565 & & \\
\hline & & & \multirow{3}{*}{\multicolumn{2}{|c|}{ Bartlett's Test of Sphericit }} & \multicolumn{2}{|c|}{ Approx. Chi-Square } & 187.85 & & \\
\hline & & & & & \multicolumn{2}{|c|}{$\mathrm{df}$} & 36 & & \\
\hline & & & & & \multicolumn{2}{|l|}{ Sig. } & 0.000 & & \\
\hline
\end{tabular}

Table 5: Total Variance Explained (a)

\begin{tabular}{|c|c|c|c|c|c|c|c|c|c|}
\hline \multirow{2}{*}{$\begin{array}{c}\text { Compo- } \\
\text { nent }\end{array}$} & \multicolumn{3}{|c|}{ Initial Eigenvalues } & \multicolumn{3}{c|}{$\begin{array}{c}\text { Extraction Sums of } \\
\text { Squared Loadings }\end{array}$} & \multicolumn{3}{|c|}{$\begin{array}{c}\text { Rotation Sums of } \\
\text { Squared Loadings }\end{array}$} \\
\cline { 2 - 10 } & Total & $\begin{array}{c}\text { \% of Vari- } \\
\text { ance }\end{array}$ & $\begin{array}{c}\text { Cumula- } \\
\text { tive \% }\end{array}$ & Total & $\begin{array}{c}\% \text { of Vari- } \\
\text { ance }\end{array}$ & $\begin{array}{c}\text { Cumula- } \\
\text { tive \% }\end{array}$ & Total & $\begin{array}{c}\% \text { of Vari- } \\
\text { ance }\end{array}$ & $\begin{array}{c}\text { Cumula- } \\
\text { tive \% }\end{array}$ \\
\hline 1 & 6.81 & 69.75 & 69.75 & 6.81 & 69.75 & 69.75 & 6.75 & 73.09 & 73.09 \\
\hline 2 & 1.47 & 19.89 & 89.64 & 1.47 & 15.54 & 85.29 & 1.52 & 11.93 & 85.02 \\
\hline 3 & 0.47 & 6.22 & 95.86 & & & & & & \\
\hline 4 & 0.10 & 2.18 & 98.04 & & & & & & \\
\hline 5 & 0.07 & 0.79 & 98.83 & & & & & & \\
\hline 6 & 0.04 & 0.67 & 99.50 & & & & & & \\
\hline 7 & 0.02 & 0.43 & 99.93 & & & & & & \\
\hline 8 & 0.00 & 0.04 & 99.97 & & & & & & \\
\hline 9 & 0.00 & 0.02 & 100.00 & & & & & & \\
\hline
\end{tabular}

Extraction Method: Principal Component Analysis. a Only cases for CSE are used in the analysis phase.

Table 6: Model Summary for Regression

\begin{tabular}{|c|c|c|c|c|c|c|c|c|c|c|}
\hline$\widetilde{\nabla}$ & \multicolumn{2}{|c|}{$\mathrm{R}$} & $\mathrm{R}^{2}$ & Adj. $\mathrm{R}^{2}$ & $\begin{array}{l}\text { Std. Error of } \\
\text { the Estimate }\end{array}$ & \multicolumn{5}{c|}{ Change Statistics } \\
\hline & CSE (Selected) & CSE (Unsel.) & & & & $\mathrm{R}^{2}$ Change & F Change & df1 & df2 & Sig. F Change \\
\hline 1 & $0.95(\mathrm{a})$ & 0.96 & 0.93 & 0.90 & 1014.56 & 0.93 & 13.89 & 8 & 6 & 0.001 \\
\hline
\end{tabular}

a Predictors: (Constant), Initial Public Offering (IPOs), Market Capitalization, Cash Dividend, No. of Listed Securities, Issued Capital, Price Index, GDP.

$b$ Unless noted otherwise, statistics are based only on cases for CSE. c Dependent Variable: Turnover 